\title{
ALS患者の在宅医療をめぐる 諸問題
}

川村佐和子

\section{1．在宅ALS療養者のケア課題}

ALSは病名Amyotrophic Lateral Screlosis： 筋萎縮性側策硬化症の略称である。原因は不明 だが全身の運動筋群を司る神経が障害を受け、身 体運動、嚥下、排泄、呼吸などに関する運動機能 や、言語などのコミュニケーション機能が障害さ れる進行性の疾患である。経過は従来では 4 年程 度とされていたが、人工呼吸器を装着するなどの 医療処置と適切かつ継続的なケアにより $20 〜 30$ 年間におよび生活する人々も増えている。

ALSにより障害を受け人工呼吸器を装着して いる1人、橋本操さんはその状態を「動けません し、もちろん声も出ません。たとえて言えば、 カナシバリでしょうか」(1) と表現している。橋 本さんは切羽詰まる身体的な異常やさまざまな 生活上の要求を口唇の動き、まばたき、透明な 板に書いた五十音表、わずかな身体の動きによ って操作されるパソコンによって生活している。 傍らにはたえず、彼女の様子を見続け、人工呼 吸器の作動音があらわす呼吸状態に耳を離さな い人たちがいる。

世の中には多くの障害によってたえず傍らに介 護者を必要とする人々がいるものである。ALSな ど呼吸の障害を抱え、さらにコミュニケーション の障害を重複している場合には傍らにいる介護者 の絶え間ない注意と適切なケアによって生命が維 持されるという点に介護の重要性がある。
現在、在宅医療で用いられている人工呼吸法 は、大別すると 2 種類あり、一つは鼻マスク式と 呼ばれ顔面にマスクを掛け空気を送入し呼吸を 補助する方法、一つは䅡部の皮膚から気管を切 開し、気管カニューレという管を装着しそこか ら空気を直接送入する方法である。ALSの場合、 平成15年度のALS患者調査では後者の利用者が $95.6 \%$ と多数であった ${ }^{(2)}$ 。

ケアに関する課題についてみると、前者では 創傷もなく適切に装着することが基本的なケア となる。しかし、後者では気管切開創に気管力 ニューレを挿着しているためにたんの量が多く、 また貯留しているたんを除去するには気管カニ ユーレにカテーテルを挿入し吸引器で陰圧をか けて吸い取らなければならない。この際のケア 課題は、人工呼吸器を取り外すこと、気管切開 創からカテーテルを挿入し陰圧をかけるため不 適切なやり方をすると感染や気管支閉塞を起こ すこと、そして挿入するカテーテルの長さによ っては気管カニューレからはずれて直接気管支 壁を傷つけること等があげられる。たんの吸引 は、1日80回を数える場合もありほぼ1時間に1 回程度はニーズがある。しかし、吸引ニーズは 定期的なものではないため、介護者は寸時も障 害者のそばを離れられない。また、夜間の吸引 は介護者の睡眠を妨げ過重な負担を与えている。

付言すれば、在宅サービスであっても吸引行 為は医師法第 17 条、保健師助産師看護師法第 
37 条による医行為であり、医師および医師の指 示を得た看護師によって行われるべき行為とさ れている。本来であれば訪問看護師によって24 時間365日行われるべきであるのだが、これは 現実的に困難であるため事実上は非医療系職員 およびボランティアなど無資格者によって行わ れているという実態が生じていた。

\section{ALSによる障害者と人工呼吸器}

わが国において、ALSによる呼吸障害を克服 するために在宅人工呼吸療法が組織的に行われ た記載は昭和50年である。この経験は東京都内 であったが、平成15年のALS患者調査では 1327 人 (全ALS患者の $27 \%)$ が呼吸器を装着と回答し て打り ${ }^{(2)}$ 今では気管切開による人工呼吸器療法 が全国各地で行われるようになった。

ALSの場合、換気不全は改善困難であるため、 長期間、全面的に介護を受けて生活することに なる。そのほとんどが家族介護に依存しなけれ ばならないため、ALSによる障害者は自身の生 活と家族の負担の相克に悩んでいる。

3 人の子どもを持つ定金信子さん壵着の悩み と呼吸器装着による呼吸苦からの解放を次のよ うに語っている。「ずいぶん悩んだ。それまでの 石ころのようにただ転がっているだけの生活に 生きがいが見つからなかった」、また最期の選択 には死を選ぶ自由も欲しいと望んだ。しかし、

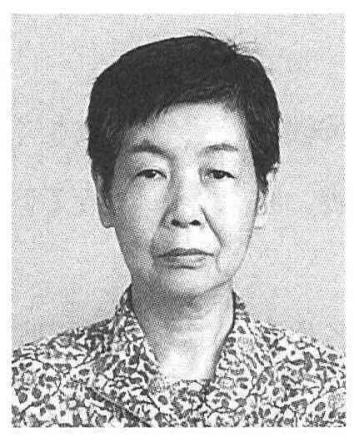

\section{PROFIIF}

川村 佐和子

（かわむら さわこ）

青森県立保健大学大学院教授

専門：看護学
仕事から帰宅し 3 人の子供と自分を介護する夫の 強い支持を受け呼吸器を装着した。「呼吸器をつ けた。空気が身体のすみずみにまで入っていく のがわかる。呼吸するだけで精いっぱいだった これまでのことを考えると、夢のようです。何 でもできそうな気がします。とにかく自分にで きることをやってみようと思いました」。こうし て被女は子どもたちの成長をしっかり見届けて いくことができる。この手記は「父さんありが とう」という題である ${ }^{(3)}$ 。

ALSは運動機能を著しく障害させることに反 して、精神活動は清明である。現在、日本ALS 協会会長を務める橋本操さんは人工呼吸器を装 着し動作すべてを介護されながら、全国各地を 回って同病者を励まし、国や自治体に交渉に出 向き、日々奔走している。その行動は每日、昼 夜を問わない。また、音楽家として飛行機で各 地を回り演奏会を開いている人もいる。農作物 の状況を判断し、耕運機に乗って地域の人々の 先頭に立って農業経営を進めている人もいる。 条件の許す限り、花見に行き、子どもの運動会 に行き、患者会に出かけ、温泉に行きと障害の ない人同様に自由に生活している人もいる。

これらの人々の活発な日々を見ていると、人 
工呼吸器装着は苦悩の始まりではなく新たな生 活を開始する契機、原動力になっていることを 理解できる。

一方では、病名も定かでない間に呼吸障害が 進行して緊急搬送され意識障害下で呼吸器を装 着している場合もある。このような場合には、 時とすると、人工呼吸器装着の知識を事前にも ち、装着の意思を表明したかったという考えが 強く表明される場合も生じる。

また、 10 年 20 年という長年月にわたる療養生 活では当然起こりうる、身体的変化や生活観の 変化、家族構成の変化などが生じる。これらを 背景として、ALS障害者の考え方や精神状態に も変化が生じてくる。自由に動けない苦痛、機 械に強制されて生きているという感覚、機械の 損傷などによる事故不安、孤独や死の恐怖、家 族の健康 - 生活問題や不在、経済的な問題など さまざまな内容である。中には一時的な反応も あるし 長期にわたっており（澱）がたまってい く場合もある。

\section{3. 重複障害を支える社会制度}

以上のように、ALSによる在宅人工呼吸療養を 行う障害者は医療と福祉の専門的知識や技術を必 要として打り、いわゆる重度重複障害をもつ人々 である。このような状態に対応する社会制度は従 来であれば医療と福祉の両制度に分離され、双方 を統合した支援、夜間支援、質 (専門的支援) ・量 の不足という課題に直面していた。

特にたんの吸引は前述したとおり、家族の介
護負担を重くするものであり、夜間介護支援の 充実の必要性が以前より問題視されていた。

平成14年11月、ALS患者家族の組織である日 本ALS協会は国に対して「ALS等の吸引を必要 とする患者に、医師の指導を受けたへルパー等、 介護者が日常生活の場で吸引することを認めて 下さい」という要望書を提出した。

これを受けて国は看護師等によるALS患者の 在宅療養支援に関する分科会 (親委員会は新た な看護のあり方に関する検討会) を設置し、こ こで以下の結論を得た。

1）たんの吸引はその危険性を考慮すれば、医師、 看護師が行うことが原則である。(医行為)

2) ALS患者に対する家族以外の者 (医師、看護 職員を除く）によるたんの吸引については、 医師及び看護職員により充分にサービスが提 供されるならば、実施する必要はないと考え られる。

しかし、たんの吸引は頻繁に行う必要があ ることから、医師や看護師によるたんの吸引 にくわえて、家族が行っているのが現状であ り、家族の負担軽減が求められている。

3）そこで、家族以外の者によるたんの吸引の実 施についても、一定の条件の下では、当面の 措置として行うこともやむを得ないものと考 えられる。

4）この場合においても、医療サービスを受ける 機会が閉ざされることのないよう、医師及び 看護職員が積極的に関わっていくべきである。 5）一定の条件つまり家族以外の者が患者に対し てたんの吸引を行う場合の条件はつぎのとお 
りである。

i）療養環境の管理：病院や施設、自宅などの資 源を適切に利用できるよう療養環境を整える こと。

ii）在宅患者の適切な医学的管理 : 在宅医療や訪 問看護によって適切な医学的な管理を継続し ていること。

iii）家族以外の者に対する教育 : 家族以外の者 は当該の患者に必要な知識及びたんの吸引の 方法を習得する。(主治医・訪問看護師から 個別化された吸引法を継続的に習得する)

iv）患者との関係：患者は必要な知識及びたんの 吸引の方法を習得した家族以外の者に対して 自己のたんの吸引を実施することについて、 文書により同意する。なお、この際、患者の 自由意思に基づいて同意がなされるよう配慮 が必要である。

v) 医師及び看護職員との連携による適正なたん の吸引の実施：例えば介護職員は医療職員と の関係について定めがあるわけではない。そ のため、うまく連携がとれないまま吸引が行 われ、安全性の確保に支障が生じてはいけな い。医行為である吸引が安全に行われるため に吸引を行う家族以外の者と医療職員らが円 滑に継続的に連携していること。

vi）緊急時の連絡・支援体制の確保：いつ生じ るかわからない緊急事態のためにホットライ ンが必要である。事前に主治医や訪問看護 師、支援者の連絡先名簿を作成しておいた り、救急車の手配法などを協議しておいた り、事前の備えをして安全を確保すること。
こうして、たんの吸引という医行為は一定の 条件のもとに資格の有無を問わず誰でもが行う ことが容認された。

吸引はALSによる障害者だけの問題ではない。 筋ジストロフィーや障害児、遷延性意識障害者 などで吸引を必要としている在宅者も多いと推 察されている。このことは看護師等によるALS 患者の在宅療養支援に関する分科会に扔いても 多くの団体が状況を訴えたところである。とく に遷延性意識障害者の組織からの訴えは強いも のであった。

国は引き続き平成 16 年 5 月から「在宅及び養 護学校に打ける日常的な医療の医学的・法律学 的整理に関する研究」班を組織し、(1)ALS以外 の在宅患者に対するたんの吸引行為に関する医 学的・法律学的整理、(2)養護学校における医療 ニーズの高い児童生徒に対する，<aたんの吸 引、 $b$ 経管栄養、 $c$ 自己導尿の補助 $>$ に関する医 学的・法律学的整理を研究課題に対置した。研 究班はALS以外の在宅療養患者・障害者に対す る家族以外の者によるたんの吸引の取り扱いに ついてALS患者に準じたとりまとめを行い、こ れを容認した。対象者の範囲は、個別の疾患名 や障害名で特定することは困難であると考え、 病状または障害が在宅生活が可能な程度に安定 しており訪問看護を利用しているなど医師によ る医学的管理下にある者であって、嬹下機能及 び呼吸機能の悪化により自力で排たんすること が困難な状態が持続し、長期にわたってたんの 吸引が必要な者とした。国から通知文書が平成 16年11月に発出された。 
また 盲・聾・養護学校における一般教員が たんの吸引、経管栄養及び導尿について、看護 師との連携・協力の下にこれらの行為の一部を 行うことも容認された。

これらのことによって、在宅でたんの吸引を 必要とする人々に対するたんの吸引は個別的な 条件を満たしていれば広く支援者を得られる状 況に入ったといえる。

さらに、国は医師法17条保助看法31条の解勫 について平成 17 年 3 月にパブリックコメントを 求め、その後、事前の同意や障害者の状態およ び医師の処方による薬剤に関するなどとする条 件の下に、水銀・電子体温計による体温・血圧 の測定、新生児以外で入院治療の必要がない者 に対するパルスオキシメーターの装着、軽微な 切り傷・擦り傷・やけど等、専門的な判断や技 術を必要としない処置を医行為とするのは拡大 解釈であるとの通知を発出した。

これらのように、在宅医療が進展しつつある 中で、従来では専門的知識や技術を必要とする とされていた行為が一般化されるようになって きた。しかし、安全性を保障するシステムは未 だ整備されているとはいえない。平成15年度の 在宅ALS患者調査 (全国の回答者数：683人)で は、退院時に主治医から病状の説明を受けた者 は $88.6 \%$ 、退院後行う人工呼吸器の扱いや吸引 の技術指導を受けた者は $85.7 \% 、 86.7 \%$ 、緊急 時に入院できる病院のあるもの $90 \%$ 、往診を受 けられるもの $86.1 \%$ あ゙あ、昨年1年間の呼吸器 トラブルの遭遇者は $52.1 \%$ あ゙あた。また家族 以外の者から吸引を受けている者は $31.9 \%$ 、そ
のうち研修を受けた実施者は $84.9 \%$ 、フォロー アップのための定期的研修を受けている実施者 は34.9\%であった。支援内容の重大性から考え

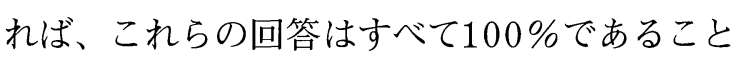
が求められる。

また、患者組織役員からは現在の在宅療養者 たちは未だ希少例として地域のボランティア活 動によって支援されているところが多く、吸引 行為の一般化を容認する環境や安全性をモニタ 一する社会機構が未整備であり、患者の安全を 優先した制度の確立を急ぐべきとの指摘もある。 前述した調查は利用者側の回答によるものであ り、客観的にリスク予防としてどのように有効 性を持つものであるか、いつでもどこでもこの ような体制をとれるのかは検証されていない。 吸引行為が容認されたとはいえ、家族以外の者 に対する行為に経済的保証や責任体制は未解決 な点が多い。

医療制度改革が進行し、入院期間短縮の結果、 入院を継続できない人々が在宅生活にあふれ出 ている今日、入院医療と同じく、在宅で生活す る重度重複障害者の安全な生活を保障すること は重要な課題である。

\section{参考文献}

(1) 厚生労働科学特別研究事業、ALS患者にかかる在宅療養 環境整備状況に関する調査研究、平成 15 年度報告書、主 任研究員川村佐和子、2004年3月

（2）立岩真也『ALS不動の機械と息する機械』医学書院、 2004年11月、p.271

（3）定金信子『父さんありがとう、いのち燃やさん』日本ALS 協会編p.98-99 1987年、静山社 